\title{
Model spasial distribusi habitat orangutan kalimantan (Pongo pygmaeus wurmbii) menggunakan logistik regresi di DAS Katingan
}

\author{
Spatial distribution model of Bornean Orangutan (Pongo pygmaeus wurmbii) habitat using \\ logistic regression in Katingan watershed \\ Mustofa $^{a}$, Syartinilia ${ }^{b}$, Hadi Susilo Arifin \\ ${ }^{\text {a }}$ Program Studi Ilmu Pengelolaan Sumberdaya Alam dan Lingkungan, Sekolah Pascasarjana, Institut Pertanian Bogor, Kampus IPB \\ Darmaga Bogor, 16680, Indonesia [+62 82113309199 ] \\ ${ }^{\mathrm{b}}$ Departemen Arsitektur Lanskap, Fakultas Pertanian, Institut Pertanian Bogor, Kampus IPB Darmaga Bogor, 16680, Indonesia
}

\section{Article Info:}

Received: 09 - 07 - 2020

Accepted: 19 - 10 - 2020

Keywords:

Habitat suitability, isolated habitat, logistic regression,

Pongo pygmaeus wrumbii

Corresponding Author:

Mustofa

Program Studi Ilmu Pengelolaan

Sumberdaya Alam dan

Lingkungan, Sekolah

Pascasarjana, Institut Pertanian

Bogor;

Tel. +6282113309199

Email:

mustofa.fato@gmail.com

\begin{abstract}
Katingan watershed is a one of bornean orangutan (Pongo pygmaeus wrumbii) habitat that currently Critically Endangered status, and protected by Indonesian government regulations (P.106/2018), that included in Appendix 1. The condition of the bornean orangutan habitat is increasingly threatened by land cover changes. Management habitat is needed to protect the populations of bornean orangutan. The aim of this research was to develop the spatial distribution model of bornean orangutan habitat as a reference to habitat management. Habitat suitability model of bornean orangutan develop by logistic regression and based on five environmental variables covering elevation, distance from cultural sites, distance from roads, distance from settlements, and NDVI. The Hosmer-Lemeshow test showing feasibility value was 0.481 with Nagelker $R^{2}=0.866$, and Kappa Accuracy $77 \%$. The total habitat suitability of bornean orangutan in the Katingan watershed was 1,250,174.35 ha (64.11\% of the Katingan watershed area). The main habitat of bornean orangutan was identified in the National Park (TN), Protection Forest (HL), and Nature Reserve/Nature Conservation Area (KSA/KPA) with area $395,178.30$ ha $(31.66 \%$ of the total habitat area). Isolated habitat identified in the north-eastern of the Katingan watershed. Habitat corridors can be created in forested areas with a minimum width of 500 meters.
\end{abstract}

How to cite (CSE Style $8^{\text {th }}$ Edition):

Mustofa, Syartinilia, Arifin HS. 2020. Model spasial distribusi habitat orangutan kalimantan (Pongo pygmaeus wurmbii) menggunakan logistik regresi di DAS Katingan. JPSL 10(4): 627-638. http://dx.doi.org/10.29244/jpsl.10.4.627-638.

\section{PENDAHULUAN}

DAS Katingan merupakan salah satu habitat orangutan kalimantan (Pongo pygmaeus wurmbii) (Wich et al., 2008) yang statusnya hampir punah (IUCN, 2016) dan apendiks 1 (CITES, 2017). Spesies ini juga termasuk spesies yang dilindungi oleh Pemerintah Indonesia melalui peraturan Menteri Lingkungan Hidup dan Kehutanan Nomor P.106 tahun 2018, serta merupakan 25 spesies prioritas di Indonesia yang populasinya harus ditingkatkan 10\% sampai tahun 2019. DAS Katingan berada diantara dua Taman Nasional (TN) yaitu TN Sebangau di bagian selatan dan TN Bukit Baka-Bukit Raya pada bagian utara. Kedua Taman Nasional tersebut merupakan habitat asli dari orangutan kalimantan. Menurut Purwadi (2010), populasi terbesar orangutan di Kalimantan Tengah dapat dijumpai di TN Sebangau. Sedangkan TN Bukit Baka-Bukit Raya menjadi tempat 
untuk pelepasliaran orangutan. Hal tersebut menjadikan DAS Katingan mempunyai fungsi yang strategis dan penting dalam menjaga ketersembungan habitat orangutan kalimantan.

Orangutan merupakan spesies payung, yaitu spesies yang mempunyai fungsi sebagai perlindungan terhadap sebagian besar spesies lainnya secara alami (Roberge dan Angelstam, 2004). Jumlah populasinya diprediksi hanya tersisa 38200 individu (Ditjen KSDAE, 2019). Keberadaan orangutan kalimantan ini terancam oleh perburuan, sedangkan habitatnya semakin berkurang akibat dari perubahan penggunaan lahan. Perubahan lingkungan terhadap suatu habitat dapat memengaruhi tingkah laku yang menyebabkan ketergantungan bahkan sifat toleransi (Pangestu et al., 2019). Habitat orangutan tersebar secara parsial (fragment) dengan jarak yang berbeda-beda dalam bentuk patch-patch hutan (Wich et al., 2008) sehingga perlu adanya pengelolaan (Xun et al., 2014). Manajemen habitat ini dapat digunakan pada habitat terisolasi.

Semakin pesatnya pembangunan dan eksploitasi sumber daya alam berbasis lahan membuat keberadaan orangutan kalimantan beserta habitatnya semakin terdesak (Utami-Atmoko et al., 2017). Eksploitasi sumber daya alam yang berlebihan dapat merusak biodiversitas serta merugikan manusia sendiri (Susilawati et al., 2020). Selain itu, laju degradasi hutan yang terus meningkat menyebabkan semakin sempitnya habitat orangutan (Rijksen dan Meijaard, 1999). Berdasarkan permasalahan tersebut, maka tujuan dari penelitian ini adalah membuat model distribusi habitat orangutan kalimantan di DAS Katingan serta memberikan rekomendasi manajemen habitatnya.

\section{METODE}

\section{Lokasi dan Waktu Penelitian}

Lokasi penelitian ini dilakukan pada satu DAS Katingan, Kalimantan Tengah dengan koordinat

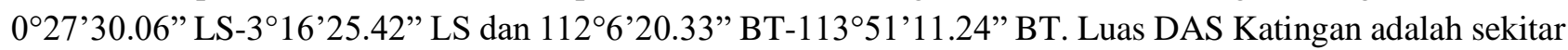
1950126.76 ha. Waktu yang diperlukan untuk menyelesaikan penelitian ini selama 3 bulan dari bulan November 2019 sampai Januari 2020. Peta lokasi penelitian dapat dilihat pada Gambar 1.

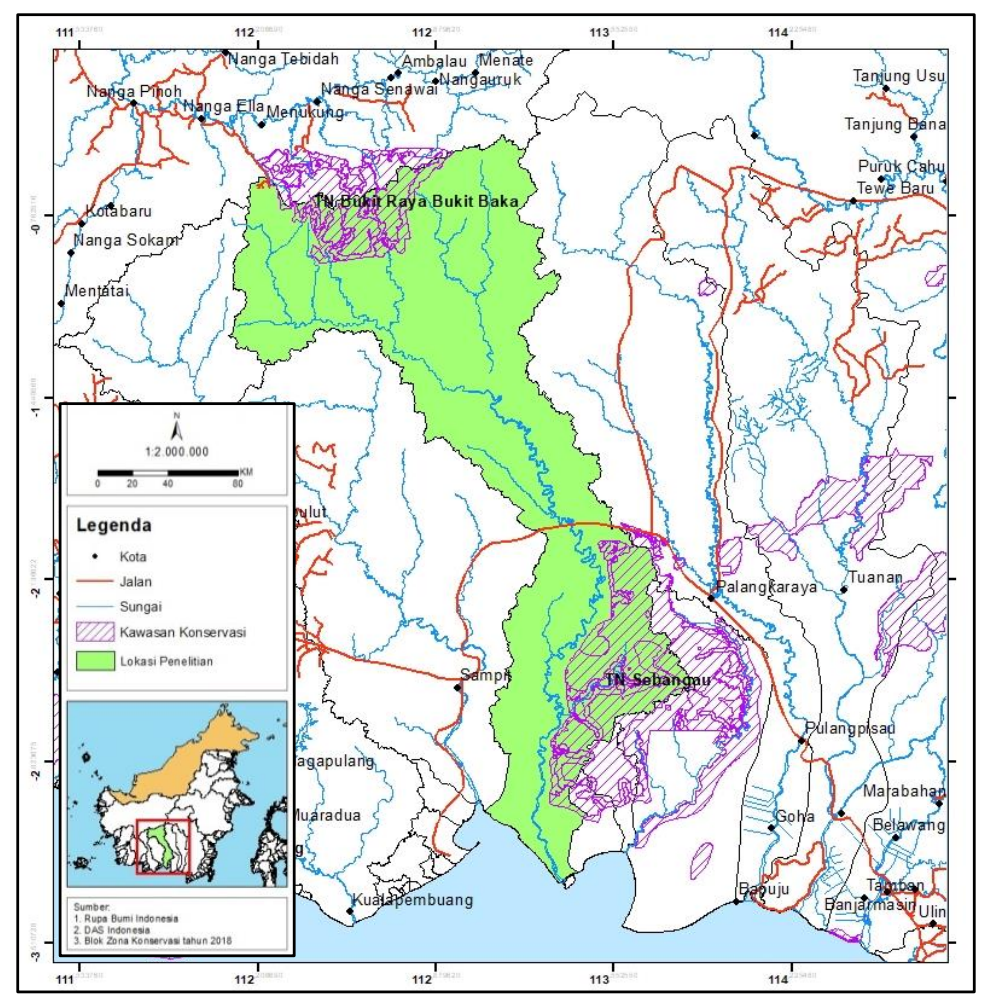

Gambar 1 Lokasi penelitian 


\section{Metode Pengumpulan Data}

Metode pengumpulan data dilakukan dengan pengamatan langsung di lokasi penelitian (data primer) dan pengumpulan dari sumber lain (data sekunder). Data yang didapatkan langsung dari lapang yaitu data kehadiran (presence) dan ketidakhadiran (absence) orangutan kalimantan, kondisi tutupan lahan, serta data situs kultural lokal masyarakat. Metode pengumpulan data lapangan kehadiran orangutan menggunakan metode eksplorasi pada lokasi yang diduga menjadi habitat orangutan. Eksplorasi ini dilakukan sekali pada setiap lokasi dan diperkuat dengan informasi wawancara dengan masyarakat lokal. Pada lokasi tersebut dilakukan penandaan (marking) menggunakan GPS serta pengambilan gambar kondisi tutupan lahan. Data kehadiran juga didapatkan dari sumber lain yaitu dari Laporan Orangutan Population and Habitat Viability Assessment-PHVA tahun 2016 serta dari gbif.org (akses tahun 2020). Jumlah titik data kehadiran orangutan hasil pengamatan langsung dan data dari sumber lain digabungkan dan digunakan sebagai variabel terikat pembentukan model distribusi habitat orangutan kalimantan.

Pengambilan data situs kultural lokal dilakukan dengan metode kunjungan ke desa-desa kemudian melakukan penandaan dan pengambilan gambar pada lokasi situs kultural masyarakat lokal. Data spasial yang digunakan antara lain data citra Landsat 8 (Path/Row 118/61, 118/62, 119/60, 119/61, 119/62 tahun 20192020) dan ASTER GDEM resolusi 30 meter yang didapatkan dari earthexplorer.usgs.gov. Data spasial lainnya yaitu batas DAS, sungai, jalan, dan pemukiman yang didapatkan dari peta Rupa Bumi Indonesia (RBI). Selain itu, digunakan juga data Peta Penutupan Lahan dari Kementerian Lingkungan dan Kehutanan tahun 2018 dan Fungsi Kawasan Hutan tahun 2016. Data yang digunakan dalam penelitian dan sumbernya dapat dilihat pada Tabel 1.

Tabel 1 Dataset dan sumber data penelitian

\begin{tabular}{ll}
\hline \multicolumn{1}{c}{ Dataset } & \multicolumn{1}{c}{ Sumber Data } \\
\hline Kehadiran orangutan (presence) & - Data primer (survei lapangan) \\
& - Data sekunder (PHVA dan gbif.org) \\
Ketidakhadiran orangutan (absence) & Data primer (survei lapangan) \\
Citra landsat 8 & https://earthexplorer.usgs.gov/ \\
Digital Elevation Model (DEM) & https://earthexplorer.usgs.gov/ \\
Jaringan sungai & Peta Rupa Bumi Indonesia \\
Jaringan jalan & Peta Rupa Bumi Indonesia \\
Sebaran pemukiman/desa & Peta Rupa Bumi Indonesia \\
Situs kultural lokal & Data primer (survei lapangan) \\
Tutupan hutan dan bukan hutan & Peta Penutupan Hutan KLHK tahun 2018 \\
\hline
\end{tabular}

\section{Metode Analisis Data}

\section{Analisis Habitat Orangutan Kalimantan}

Habitat memiliki peranan bagi satwa liar sebagai tempat untuk mencari makan, minum dan tempat berlindung (Alikodra, 2002). Pemodelan kesesuaian habitat orangutan kalimantan merupakan proses peninjauan dan penilaian kebutuhan hidup (life requisites) orangutan kalimantan terhadap faktor-faktor habitat dan faktor-faktor gangguan. Kelengkapan habitat terdiri dari berbagai macam jenis termasuk makanan, perlindungan, dan faktor-faktor lainnya yang diperlukan oleh spesies hidupan liar untuk bertahan hidup dan melangsungkan reproduksinya secara berhasil (Bailey, 1984). Total ada 8 variabel yang digunakan pada pembuatan model distribusi habitat orangutan kalimantan, yaitu ketinggian tempat, kemiringan lereng, jarak dari sungai, jarak dari jalan, jarak dari pemukiman, jarak dari hutan, jarak dari situs kultural, dan Normalization Difference Vegetation Index (NDVI). Faktor-faktor habitat yang digunakan yaitu ketersediaan air yang diwakili oleh jarak dari sungai, serta ketersediaan vegetasi yang diwakili oleh nilai NDVI dan jarak dari hutan. Faktor perlindungan diwakili oleh variabel ketinggian tempat dan kemiringan lereng. Faktor gangguan berasal 
dari aktivitas manusia yang diidentifikasi melalui jarak dari jalan, jarak dari pemukiman, dan jarak dari situs kultural lokal masyarakat.

Peta jarak dari sungai, jalan, pemukiman, hutan, dan situs kultural lokal dianalisis menggunakan euclidean distance pada ArcGIS 10.4.1. Peta ketinggian tempat dan kemiringan lereng menggunakan data Digital Elevation Model (DEM). Sedangkan NDVI diukur dengan mengambil band (saluran gelombang cahaya) warna merah ( $\mathrm{R}=$ red light) dan infra merah ( $\mathrm{NIR}=$ near infrared) yang didapatkan dari Landsat 8 . Perhitungan NDVI dilakukan pada model maker ERDAS dengan menggunakan persamaan:

$$
N D V I=\frac{N I R-R}{N I R+R}
$$

Peta variabel lingkungan yang digunakan untuk membuat model distribusi habitat orangutan kalimantan dapat dilihat pada Gambar 2 berikut ini.

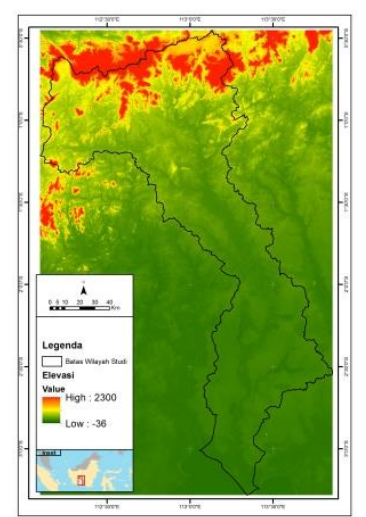

(a)

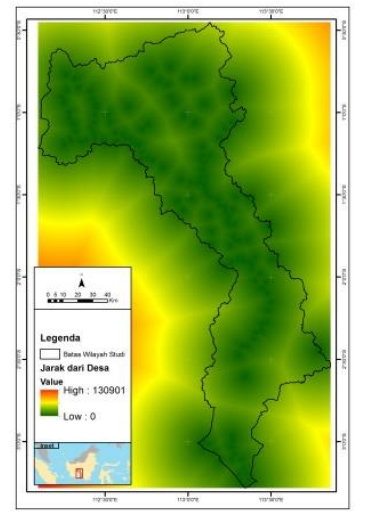

(e)

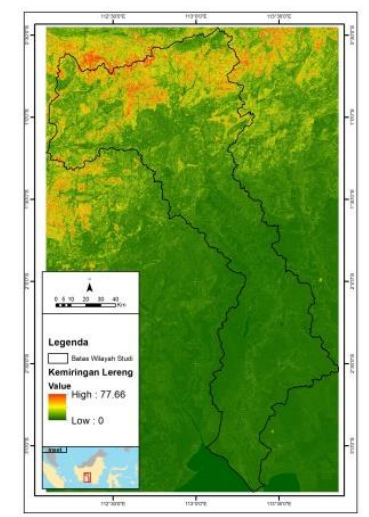

(b)

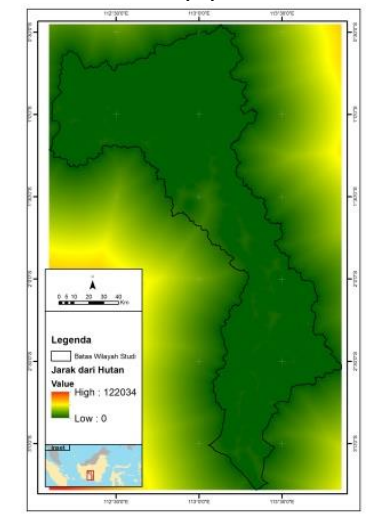

(f)

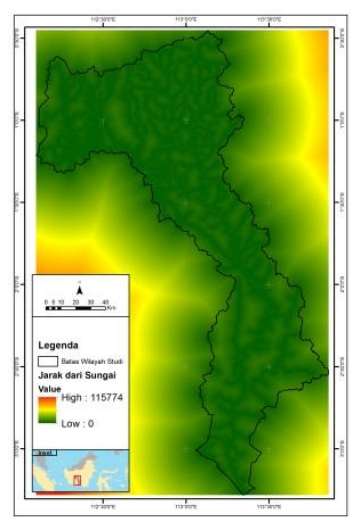

(c)

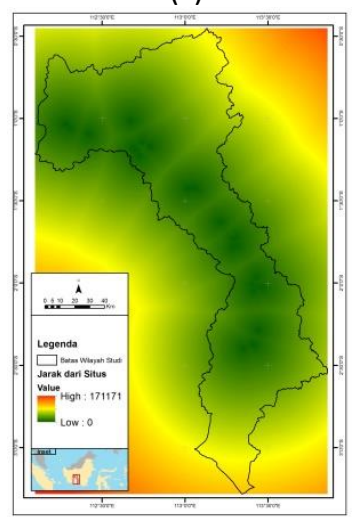

(g)

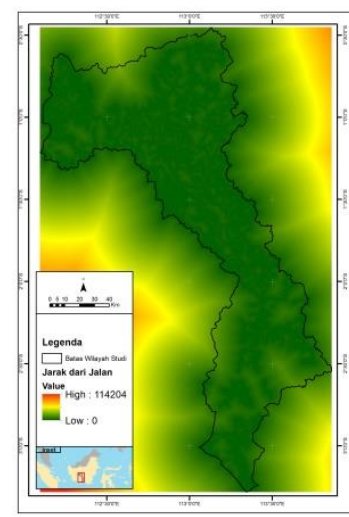

(d)

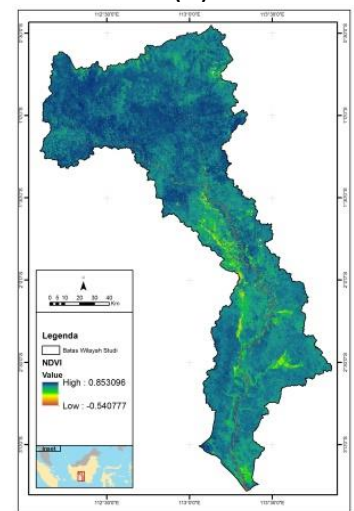

(h)

Gambar 2 Variabel lingkungan (a) ketinggian tempat; (b) kemiringan lereng; (c) jarak dari sungai; (d) jarak dari jalan; (e) jarak dari pemukiman; (f) jarak dari hutan; (g) jarak dari situs kultural; dan (h) NDVI

Selain variabel lingkungan, data yang digunakan dalam analisis habitat orangutan kalimantan yaitu data perjumpaan (kehadiran/presence dan ketidakhadiran/absence) sebagai variabel terikat. Jumlah titik secara keseluruhan adalah 152 titik (68 titik presence; 84 titik absence). Titik presence didapatkan dari hasil lapangan (2 titik) dan dari kajian sebelumnya (PHVA 65 titik; GBIF 1 titik), sedangkan titik absence seluruhnya didapatkan dari hasil lapangan. Data titik kehadiran hasil lapangan mempunyai peran penting dalam pembentukan model distribusi habitat meskipun jumlahnya hanya 2 titik. Titik kehadiran ini dapat menjadi indikasi awal habitat sesuai ataupun sebagai titik validasi. Proporsi titik yang digunakan sebagai model 
sebanyak 70\% (106 titik) sedangkan titik yang digunakan sebagai validasi sebanyak 30\% (46 titik). Sebaran titik presence-absence dan model-validasi dapat dilihat pada Gambar 3 berikut ini.

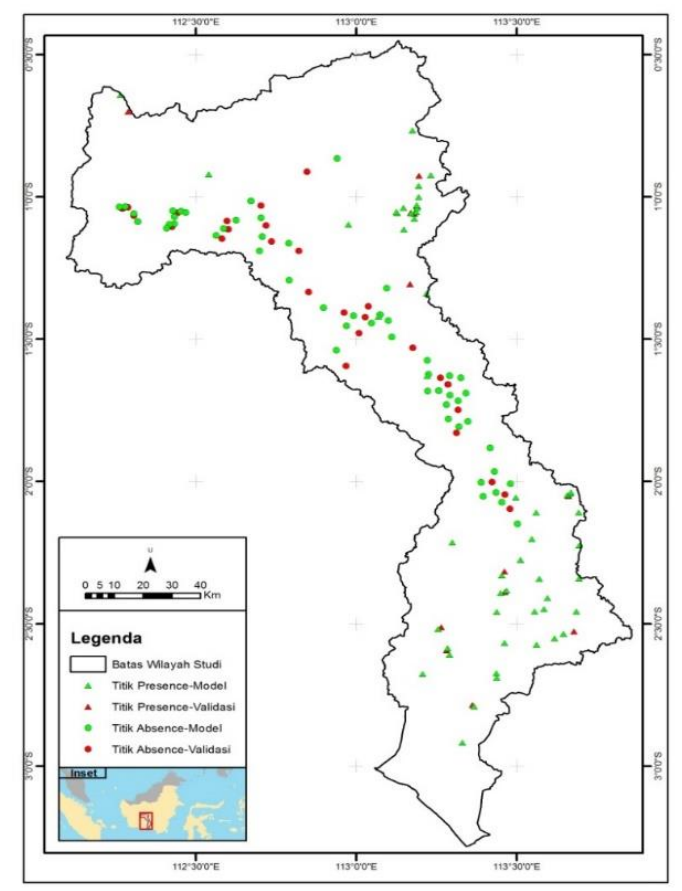

Gambar 3 Peta sebaran titik perjumpaan dan permodelan

Model distribusi habitat orangutan dibentuk menggunakan data titik perjumpaan (variabel terikat/dependent) dan variabel-variabel lingkungan (variabel bebas/independent). Variabel-variabel lingkungan tersebut terlebih dahulu diuji multikolinearitas untuk mengetahui kemungkinan adanya hubungan linear sempurna antar variabel bebas. Salah satu metode yang dapat digunakan untuk mendiagnosa ada tidaknya multikolinearitas yaitu dengan menghitung nilai toleransi atau VIF (Variance Inflation Factor). Jika nilai toleransi $<0.1$ atau nilai VIF $>10$, maka terjadi multikolinearitas atau hubungan linear sempurna antar variabel bebas sehingga variabel bebas tersebut harus dieliminasi. Analisis pembuatan model distribusi habitat orangutan kalimantan menggunakan analisis regresi logistik biner yang diolah pada SPSS 25. Rumus yang digunakan yaitu:

$$
P i=\frac{1}{1+E x p[-(\beta 0+\beta 1 X 1+\beta 2 X 2+\cdots+\beta n X n)]}
$$

dengan:

$P i$ = peluang kesesuaian habitat orangutan kalimantan

$e \quad=$ exponent bilangan natural $(=2.718281828)$

$X n=$ variabel penduga ke- $n$

$\beta 0=$ intersep atau konstanta persamaan

$\beta n=$ koefisien dari variabel penduga ke-n

Nilai peluang kesesuaian habitat orangutan kalimantan dikategorikan menjadi dua kategori. Nilai peluang $0<\mathrm{Pi}<0.5$ dikategorikan sebagai area yang tidak sesuai untuk habitat orangutan kalimantan, sedangkan nilai peluang $0.5<\mathrm{Pi}<1$ dikategorikan sebagai area yang sesuai. Nilai ambang batas (threshold) 0.5 ini telah digunakan secara luas dalam pendugaan distribusi spesies (Manel et al., 1999; Stockwell dan Peterson, 2002).

Uji kelayakan model menggunakan uji Hosmer-Lemeshow. Uji Hosmer-Lameshow cocok untuk model yang terdiri dari beberapa variabel bebas yang bernilai diskrit ataupun kontinu (Hosmer et al., 1997). Variabel bebas dinyatakan cocok (fit) dengan model jika signifikansi pada hasil uji Hosmer-Lemeshow di atas 0.05. 
Koefisien determinasi $\left(\mathrm{R}^{2}\right)$ ditentukan dengan melihat hasil uji Nagelkerke $\mathrm{R}^{2}$ dan percentage correct (overall percentage). Nagelkerke $\mathrm{R}^{2}$ menunjukkan tingkat kepentingan variabel bebas dalam memprediksi variabel terikat. Semakin besar nilai Nagelkerke $\mathrm{R}^{2}$ yang dihasilkan maka model tersebut semakin baik. Percentage correct untuk melihat kemampuan model dalam menebak kondisi yang terjadi. Semakin besar percentage correct maka semakin baik.

Validasi model ditentukan berdasarkan Kappa Accuracy. Penggunaan Kappa Accuracy ini dapat menguji tingkat kekonsistenan dan kecermatan model distribusi habitat pada titik validasi. Selain itu, terdapat 2 kesalahan (error) yang dijumpai dalam tahap validasi model. Pertama adalah omission error, yaitu model memprediksi suatu lokasi sebagai habitat yang tidak sesuai walaupun orangutan kalimantan ditemukan pada lokasi tesebut. Kedua adalah comission error, yaitu model memprediksi suatu lokasi sebagai habitat yang sesuai namun tidak pernah ditemukan adanya orangutan kalimantan pada lokasi tersebut (Syartinilia dan Tsuyuki, 2008).

\section{Analisis Manajemen Habitat Orangutan Kalimantan}

Pengelolaan habitat berperan penting dalam konservasi sumber daya alam dan satwa liar (Saura dan Pascual-Hortal, 2007). Analisis manajemen habitat dilakukan dengan overlay peta habitat sesuai orangutan kalimantan dengan Peta Fungsi Kawasan Hutan. Area yang mempunyai fungsi sebagai kawasan konservasi atau hutan lindung ditetapkan sebagai habitat utama sedangkan area lainnya sebagai habitat penghubung. Analisis manajemen habitat ini juga memberikan rekomendasi pengelolaan pada habitat yang terisolasi dengan mempertimbangkan dari fungsi kawasan dan kondisi vegetasi tutupan hutan.

\section{HASIL DAN PEMBAHASAN}

\section{Model Distribusi Habitat Orangutan Kalimantan}

Hasil diagnosa multikolinearitas terhadap 8 variabel lingkungan (variabel bebas) didapatkan nilai toleransi yang terendah adalah pada jarak dari pemukiman (0.348), sedangkan nilai VIF yang tertinggi juga pada jarak dari pemukiman (2.87). Hal ini berarti tidak ada nilai toleransi $<0.1$ atau VIF> $>$. Hasil tersebut menunjukkan bahwa seluruh variabel bebas dapat digunakan untuk membentuk model distribusi habitat orangutan kalimantan di DAS Katingan.

Hasil analisis regresi logistik biner dengan metode Backward Stepwise (conditional) (Tabel 2) terhadap delapan variabel bebas pada step 4 mendapatkan hanya 5 variabel bebas yang dapat digunakan untuk membentuk model. Variabel tersebut yaitu elevasi (ELV), jarak dari situs kultural (STS), jarak dari jalan (JLN), jarak dari pemukiman (PMK), dan NDVI. Variabel-variabel terpilih tersebut digunakan sebagai faktor pembuatan model distribusi habitat orangutan kalimantan.

Tabel 2 Hasil analisis logistik regresi biner dengan metode Backward Stepwise (conditional)

\begin{tabular}{|c|c|c|c|c|c|c|c|c|c|}
\hline & & \multirow{2}{*}{ B } & \multirow{2}{*}{ S.E. } & \multirow{2}{*}{ Wald } & \multirow{2}{*}{$\mathrm{df}$} & \multirow{2}{*}{ Sig. } & \multirow{2}{*}{$\operatorname{Exp}(B)$} & \multicolumn{2}{|c|}{ 95\% C.I.for $\operatorname{EXP}(\mathrm{B})$} \\
\hline & & & & & & & & Lower & Upper \\
\hline \multirow[t]{6}{*}{ Step $4^{\mathrm{a}}$} & ELV & -0.0254 & 0.009 & 7.912 & 1 & 0.005 & 0.975 & 0.958 & 0.992 \\
\hline & STS & 0.0002 & 0.000 & 9.321 & 1 & 0.002 & 1.000 & 1.000 & 1.000 \\
\hline & JLN & 0.0009 & 0.000 & 3.642 & 1 & 0.056 & 1.001 & 1.000 & 1.002 \\
\hline & PMK & 0.0003 & 0.000 & 3.983 & 1 & 0.046 & 1.000 & 1.000 & 1.001 \\
\hline & NDVI & 8.6321 & 5.745 & 2.258 & 1 & 0.133 & 5609.204 & 0.072 & 435600057.759 \\
\hline & Constant & -9.0580 & 3.837 & 5.574 & 1 & 0.018 & 0.000 & & \\
\hline
\end{tabular}

Keterangan: $\mathrm{B}=$ coefficient beta $; \mathrm{S} . \mathrm{E} .=$ standard error $;$ Wald $=$ wald test $; \mathrm{df}=$ degree of freedom;

Sig.=significant $; \operatorname{Exp}(\mathrm{B})=$ exponential beta $($ odds ratio $)$ 
Berdasarkan hasil analisis di atas, model distribusi habitat orangutan kalimantan di DAS Katingan yaitu:

$$
P i=\frac{1}{1+E x p[-(0.0002 S T S+0.0009 J L N+0.0003 P M K+8.6321 N D V I-0.0254 E L V-9.0580)]}
$$

Penerapan model yang terbentuk menghasilkan model distribusi habitat orangutan kalimantan di DAS Katingan. Nilai probabilitas habitat tersebut dibagi menjadi dua kategori, yaitu tidak sesuai $(0<P i<0.5)$ dan sesuai $(0.5<P i<1)$. Hasil uji kelayakan menggunakan Hosmer-Lemeshow test menunjukkan bahwa model dinyatakan layak dengan nilai $0.483(>0.05)$. Nilai Nagelkerke $\mathrm{R}^{2}$ pada model ini sebesar 0.866 yang berarti variabel bebas yang membentuk model dapat menjelaskan sebesar $86.6 \%$ sedangkan sisanya (13.4\%) dijelaskan oleh variabel bebas lainnya. Uji validasi dengan Kappa Accuracy menghasilkan nilai sebesar 77\% yang berarti model yang terbentuk cukup valid. Uji validasi model juga menunjukkan omission error sebesar $23.8 \%$ dan comission error sebesar $22.1 \%$. Hasil penerapan model distribusi habitat orangutan kalimantan di DAS Katingan dapat dilihat pada Gambar 4.

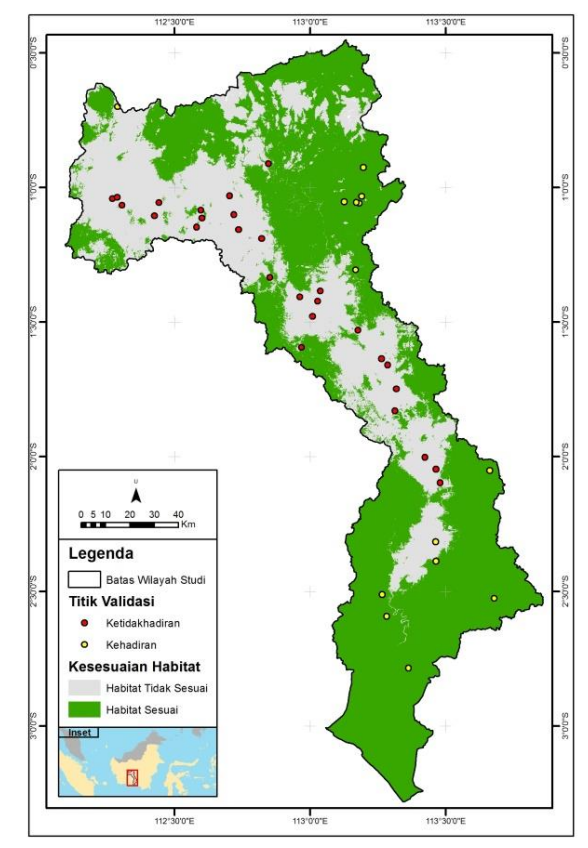

Gambar 4 Model distribusi habitat orangutan kalimantan di DAS Katingan

Penerapan model distribusi habitat orangutan kalimantan dengan menggunakan analisis spasial menghasilkan luas total distribusi habitat sesuai orangutan kalimantan di DAS Katingan adalah 1250174.35 ha atau $64.11 \%$ dari luas DAS Katingan. Menurut Alikodra (2002), suatu habitat merupakan hasil interaksi dari komponen fisik dan komponen biotik. Komponen yang membentuk habitat orangutan kalimantan di DAS Katingan merupakan kombinasi dari faktor biotik (NDVI) dan fisik (elevasi, jarak dari situs, jarak dari jalan, dan jarak dari pemukiman). Selain itu, faktor-faktor tersebut juga merupakan kombinasi dari pemenuhan kebutuhan hidup orangutan (NDVI dan elevasi) serta bentuk gangguan (jarak dari situs, jarak dari jalan, dan jarak dari pemukiman).

\section{Habitat Requirement Model Distribusi Habitat Orangutan Kalimantan}

Hasil model distribusi habitat orangutan kalimantan di DAS Katingan mendapatkan 5 variabel lingkungan yang menjadi persyaratan komponen pembentuk habitat. Komponen tersebut yaitu jarak dari situs kultural (STS), jarak dari jalan (JLN), jarak dari pemukiman (PMK), Normalization Difference Vegetation Index 
(NDVI), dan ketinggian tempat/elevasi (ELV). Komponen-komponen tersebut merupakan kombinasi dari komponen fisik dan biotik serta sumber pemenuhan kebutuhan dan gangguan.

\section{Jarak dari Situs (STS)}

Situs kultural lokal masyarakat merupakan area yang diyakini oleh masyarakat sebagai tempat keramat. Tempat-tempat tersebut antara lain kaleka (kampung lama), tajahan (tempat semedi/bertapa), petahu/nyaluh (diyakini sebagai tempat hidup roh penjaga kampung), sandung (tempat menyimpan kerangka), serta pohon tangiran (pohon madu). Area-area tersebut sebagian besar secara rutin masih digunakan oleh masyarakat Katingan, terutama suku Dayak, untuk melakukan ritual budaya. Situs kultural ini merupakan bentuk gangguan terhadapat keberadaan orangutan kalimantan karena menurut Uitgeverij dan Hoeve (2003) orangutan umumnya tidak suka dilihat atau diganggu manusia.

\section{Jarak dari Jalan (JLN)}

Bentuk gangguan lainnya yaitu jarak dari jalan. Jalan di DAS Katingan didominasi jalan perusahaan. Jalan ini hampir setiap hari menjadi akses utama bagi perusahaan maupun masyarakat untuk melakukan aktivitas. Perusahaan menggunakan jalan sebagai akses untuk mengangkut hasil hutan maupun hasil alam lainnya. Sementara masyarakat menggunakan jalan untuk aktivitas harian baik untuk pergi ke kebun dan sawah maupun untuk aktivitas lain. Jaringan jalan ini juga menjadi faktor pemutus dari pergerakan orangutan. Selain itu, jaringan jalan juga menjadi ancaman terhadap keberadaan orangutan beserta habitatnya. Aktivitas perburuan dan illegal logging sebagian besar menggunakan akses jalan ini. Perubahan habitat (luas dan kualitasnya) akibat dari illegal logging membuat orangutan tergusur dan pindah menjauhi lokasi penebangan untuk mempertahankan keberlangsungan hidupnya (Meijaard et al., 2001; Prayogo et al., 2016).

\section{Jarak dari Pemukiman (PMK)}

Komponen jarak dari pemukiman juga menjadi gangguan terhadap keberadaan orangutan dan habitatnya. Perkampungan di DAS Katingan didominasi oleh suku Dayak yang memiliki kebiasaan berburu dan ladang berpindah. Hampir setiap hari masyarakat melakukan kebiasaan tersebut untuk memenuhi kebutuhan harian. Orangutan merupakan jenis primata yang sangat sensitif terhadap perburuan (Soemarno et al., 1995). Semakin dekat dengan pemukiman, maka semakin tinggi ancaman dan gangguan habitat orangutan kalimantan.

\section{Normalization Difference Vegetation Index (NDVI)}

Komponen lain yang berpengaruh terhadap kesesuaian habitat orangutan kalimantan di DAS Katingan yaitu nilai Normalization Difference Vegetation Index (NDVI). NDVI merupakan metode standar yang digunakan untuk mengukur tingkat kehijauan vegetasi pada suatu lokasi (Siahaan et al., 2019). Indeks vegetasi adalah indeks yang menggambarkan tingkat kehijauan suatu tanaman dan merupakan kombinasi matematis antara band merah dan band NIR (Near-Infrared Radiation) yang telah lama digunakan sebagai indikator keberadaan dan kondisi vegetasi (Lillesand et al., 2004). Nilai NDVI mendekati 1 menunjukkan kondisi tutupan vegetasinya sangat baik, sedangkan pada nilai NDVI kurang dari 0 menunjukkan tidak ada vegetasi pada lokasi tersebut. Rentang nilai NDVI yang dihasilkan pada nilai -0.54 sampai 0.85 . Hasil pemodelan menunjukkan bahwa nilai koefisien yang tertinggi terdapat pada NDVI. Hal tersebut menunjukkan bahwa orangutan membutuhkan vegetasi dan pohon untuk membuat sarang maupun untuk memenuhi makan. Orangutan merupakan satwa yang arboreal. Satwa ini biasa membuat sarang di tajuk-tajuk pohon yang tertutup yang memiliki ketinggian 6 sampai $24 \mathrm{~m}$ di atas tanah (Napier dan Napier, 1985). Habitat yang baik untuk orangutan tidak hanya terdiri dari pepohonan, sebagian besar buah dan daun yang disukai sebagai makanan orangutan berasal dari liana (Rijsken dan Meijaard, 1999). 


\section{Ketinggian Tempat/Elevasi (ELV)}

Komponen ketinggian tempat (elevasi) juga menjadi pembentuk dari model kesesuaian habitat orangutan kalimantan di DAS Katingan. Ketinggian tempat di DAS Katingan berkisar pada -36 sampai 2300 meter di atas permukaan laut (mdpl). Orangutan dapat hidup pada berbagai tipe hutan, mulai hutan dipterocarpaceae dataran rendah dan perbukitan, daerah sepanjang tepi aliran sungai, hutan rawa, hutan karangas serta hutan pegunungan hingga ketinggian $1800 \mathrm{mdpl}$ (Soehartono et al., 2009). Orangutan kalimantan memiliki habitat utama di hutan rawa gambut dan hutan dataran rendah pada ketinggian diantara 200 hingga $400 \mathrm{~m}$ dpl (van Schaik et al., 1995; Wich et al., 2008). Orangutan umumnya menggunakan daerah pegunungan hanya untuk mendapatkan buah ketika di habitat utama kelimpahan buah dalam kondisi rendah (Buij et al., 2002). Hasil pemodelan habitat menunjukkan nilai koefisien elevasi sebesar -0.0254 (Tabel 2). Hal tersebut menunjukkan bahwa semakin tinggi suatu tempat maka semakin rendah kesesuaian habitat orangutan kalimantan.

\section{Rekomendasi Manajemen Habitat Orangutan Kalimantan}

Pergerakan spesies merupakan hal utama dalam dinamika populasi sehingga konektivitas menjadi penentu dalam konservasi (Nikolakaki, 2004). Hasil analisis distribusi habitat orangutan kalimantan di DAS Katingan (Gambar 4) menunjukkan bahwa bentuk habitatnya cenderung berbentuk kompak (matriks) dan ada beberapa patch-patch kecil. Manajemen habitat yang dilakukan pada penelitian ini adalah dengan menggunakan peta habitat sesuai yang dioverlay dengan Peta Fungsi Kawasan Hutan (KLHK, 2016). Terdapat 8 fungsi kawasan yang berada di DAS Katingan yaitu Area Penggunaan Lain (APL), Hutan Produksi yang dapat Dikonversi (HPK), Hutan Produksi (HP), Hutan Produksi Terbatas (HPT), Kawasan Suaka Alam/Kawasan Pelestarian Alam (KSA/KPA), Taman Nasional (TN), dan Tubuh Air (TA). Luas masingmasing habitat sesuai pada setiap fungsi kawasan disajikan pada Tabel 3 berikut ini.

Tabel 1 Luas habitat sesuai orangutan kalimantan pada setiap fungsi kawasan

\begin{tabular}{cccc}
\hline No & Habitat Sesuai pada Fungsi Kawasan & Luas (ha) & Luas (\%) \\
\hline 1 & Habitat sesuai di APL & 50488.68 & 4.04 \\
2 & Habitat sesuai di HPK & 190706.97 & 15.28 \\
3 & Habitat sesuai di HP & 411388.78 & 32.96 \\
4 & Habitat sesuai di HPT & 193136.60 & 15.47 \\
5 & Habitat sesuai di KSA/KPA & 5685.22 & 0.46 \\
6 & Habitat sesuai di HL & 33930.41 & 2.72 \\
7 & Habitat sesuai di TN & 355562.67 & 28.48 \\
8 & Habitat sesuai di Tubuh air & 7347.55 & 0.59 \\
\hline & Luas total & 1248246.88 & 100 \\
\hline
\end{tabular}

Fungsi yang terluas sebagai habitat orangutan adalah fungsi HP dengan luas 411388.78 ha (32.96\%). Pada fungsi kawasan ini, habitat orangutan relatif mudah untuk dilakukan pengelolaan. Hal tersebut dikarenakan pada pemanfaatan hutan di fungsi HP masih menyisakan tegakan yang dapat digunakan sebagai habitat orangutan kalimantan. Meskipun begitu, aktivitas perusahaan baik dalam penebangan tegakan pohon maupun dalam aktivitas harian tetap menjadi gangguan dari keberadaan orangutan kalimantan. Peta habitat sesuai pada setiap fungsi kawasan hutan dapat dilihat pada Gambar 5.

Habitat utama orangutan kalimantan di DAS Katingan ditetapkan pada habitat yang berada pada fungsi TN, HL, dan KSA/KPA. Penetapan ini didasari bahwa secara fungsi, kawasan tersebut merupakan kawasan konservasi dan lindung sehingga relatif lebih aman dari konversi fungsi lahan. Selain itu, kondisi dari vegetasi tutupan hutan di kawasan tersebut relatif lebih terjaga sehingga mendukung untuk hidup dan kembang biak orangutan kalimantan. Lokasi habitat utama berada pada sebelah utara dan timur-selatan dengan luas total 395 178.30 ha (31.66\% dari luas total habitat). Lokasi sebaran habitat utama tersebut menunjukkan bahwa perlu 
keberadaan habitat sesuai di luar habitat utama sebagai habitat penghubung yang harus dikelola untuk menjaga ketersambungan.

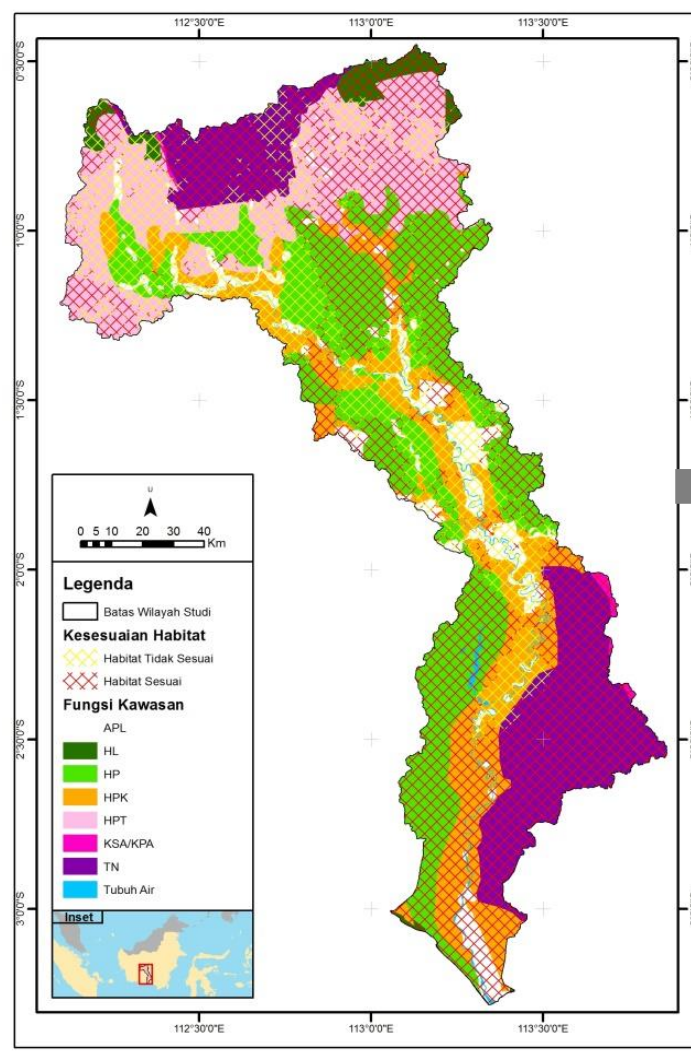

(a)

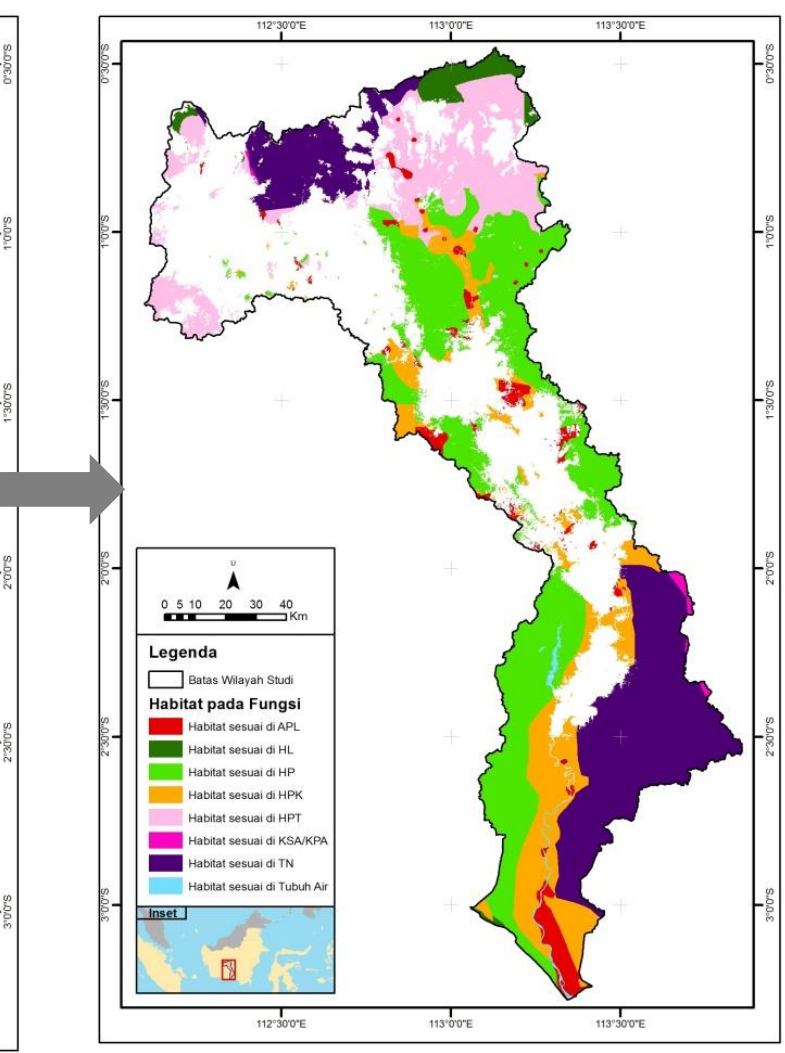

(b)

Gambar 2 Peta (a) overlay kesesuaian habitat dan fungsi kawasan; (b) habitat sesuai pada setiap fungsi kawasan

Habitat sesuai sebagai habitat penghubung berada pada fungsi APL, HPK, HP, HPT, dan TA dengan luas 853068.58 ha (68.34\%). Habitat penghubung ini penting untuk dilakukan pengelolaan strategis guna menjaga keberadaan dari habitat orangutan kalimantan. Habitat yang paling rentan adalah pada fungsi APL seluas 50 488.68 ha (4.04\%). Ancaman pada habitat fungsi APL ini adalah perubahan tutupan hutan karena pemanfaatan pada fungsi ini diperbolehkan untuk menghilangkan tutupan hutan. Hal tersebut jelas akan menghilangkan habitat orangutan kalimantan. Pada fungsi lainnya juga mempunyai ancaman yang sama terutamam pada aktivitas ilegal. Tetapi pengelolaannya lebih dapat dikontrol dibandingkan pada fungsi APL. Rekomendasi manajemen habitat pada area ini adalah dengan tetap mempertahankan membuat jalur tegakan pohon lebar koridor minimal 500 meter sesuai dengan jarak tempuh harian orangutan (MacKinnon, 1974; Maple, 1980).

Hasil analisis manajemen habitat juga memperlihatkan terdapat habitat yang terisolasi. Lokasi habitat terisolasi ini berada pada bagian timur-utara DAS Katingan yang fungsi kawasannya adalah HL dan HPT. Pada habitat terisolasi ini perlu adanya manajemen konektivitas untuk menjaga ketersambungan dengan lokasi habitat lain terutama habitat utama. Rekomendasi manajemen konektivitas yang dapat dilakukan adalah dengan membuat koridor pohon dengan lebar minimal 500 meter ataupun ecobridge dengan lebar 30 sampai 50 meter. Pembuatan koridor dengan lebar minimal 500 meter dapat dilakukan pada kawasan yang secara tata ruang tetap dipertahankan tutupan hutannya. Sedangkan pembuatan ecobridge dapat dilakukan pada wilayah yang secara tata ruang dilakukan pembangunan seperti jalan yang dapat memutus habitat orangutan. Kondisi tutupan hutan dan vegetasi serta mempertimbangkan fungsi kawasan di sekitar lokasi habitat terisolasi masih memungkinkan untuk dilakukan manajemen konektivitas tersebut. 


\section{KESIMPULAN}

Variabel lingkungan yang terpilih untuk membentuk model kesesuaiaan habitat orangutan kalimantan di DAS Katingan yaitu jarak dari situs kultural (STS), jarak dari jalan (JLN), jarak dari pemukiman (PMK), NDVI, dan elevasi (ELV). Model distribusi habitat orangutan kalimantan di DAS Katingan dengan metode Backward Stepsiwe (conditional) yaitu:

$$
P i=\frac{1}{1+\operatorname{Exp}[-(0.0002 S T S+0.0009 J L N+0.0003 P M K+8.6321 N D V I-0.0254 E L V-9.0580)]}
$$

Rekomendasi manajemen konektivitas pada habiatat utama (TN, HL, KSA/KPA) yaitu dengan mempertahankan kondisi vegetasi dan tegakan pohon. Rekomendasi manajemen konektivitas pada habitat penghubung dilakukan dengan mempertahankan/membuat tegakan pohon selebar minimal 500 meter. Rekomendasi manajemen konektivitas pada habitat terisolasi yaitu dengan membuat koridor tegakan pohon dengan lebar minimal 500 meter ataupun ecobridge dengan lebar 30 hingga 50 meter.

\section{DAFTAR PUSTAKA}

[CITES] the Convention on International Trade in Endangered Species of Wild Fauna and Flora. 2017. Apendices I, II, and III [Internet]. [diunduh 2020 Feb10]. Tersedia pada: https://cites.org/eng/app/ appendices.php.

[Ditjen KSDAE] Direktorat Jenderal Konservasi Sumber Daya Alam dan Ekosistem. 2019. Strategi dan Rencana Aksis Konservasi Orangutan Indonesia 2019-2029. Jakarta (ID): Kementerian Lingkungan Hidup dan Kehutanan Republik Indonesia.

[IUCN] International Union for Conservation of Nature. 2016. IUCN Red List of Threatened Species [Internet]. [diunduh 2020 Feb 10]. Tersedia pada: www.iucnredlist.org.

Alikodra HS. 2002. Pengelolaan Satwaliar: Jilid I. Bogor (ID): Yayasan Penerbit Fakultas Kehutanan IPB.

Bailey JA. 1984. Principles of Wildlife Management. New York (US): Wiley.

Buij R, Wich SA, Lubis AH, Sterk EHM. 2002. Seasonal movements in the Sumatran orangutan (Pongo pygmaeus abelii) and consequences for conservation. Biological Conservation. 107: 83-87. doi: 10.1016/S0006-3207(02)00048-4.

Hosmer DW, Hosmer T, Le Cessie S, Lemeshow S. 1997. A comparison of goodness-of-fit tests for the logistic regression model. Stat Med. 16: 965-980.

Lillesand TM, Kiefer RW, Chipman. 2004. Remote Sensing \& Image Interpretation: 6th-ed. New York (US): John Wiley \& Sons.

MacKinnon JR. 1972. The behaviour and ecology of the orang-utan (Pongo pygmaeus), with relation to the other apes [tesis]. Oxford (GB): University of Oxford.

Manel S, Dias JM, Ormerod SJ. 1999. Comparing discriminant analysis, neural networks and logistic regression for predicting species distributions: A case study with a Himalayan river bird. Ecological Modelling. 120: 337-347.

Maple TL. 1980. Orang-utan Behavior (Van Nostrand and Reinhold Primate Behavior and Development Series). New York (US): Van Nostrand Reinhold Company.

Meijaard E, Rijksen HD, Kartikasari SN. 2001. Di Ambang Kepunahan! Kondisi Orangutan Liar di Awal Abad ke-21. Jakarta (ID): The Gibbon Foundation Indonesia.

Napier JR, Napier PH. 1985. The Natural History of The Primates. Great Britain (GB): MIT Press.

Nikolakaki P. 2004. A GIS site-selection process for habitat creation:estimating connectivity of habitat patches. Landscape and Urban Planning. 68: 77-94. doi: 10.1016/S0169-2046(03)00167-1.

Pangestu A, Setiadi Y, Arifin HS. 2019. Keanekaragaman hayati flora habitat bekantan pada kawasan ekowisata, Kabupaten Tapin, Provinsi Kalimantan Selatan. Jurnal Ilmu Pertanian Indonesia (JIPI). 24(4): 359-365. doi: 10.18343/jipi.24.4.359. 
Pemerintah Indonesia. 2018. Peraturan Menteri Lingkungan Hidup dan Kehutanan No. P106 tahun 2018 tentang Perubahan Kedua Atas Peraturan Menteri Lingkungan Hidup dan Kehutanan Republik Indonesia Nomor P.20/MENLHK/SETJEN/KUM.1/6/2018 tentang Jenis Tumbuhan dan Satwa Dilindungi. Jakarta (ID): Kenterian Lingkungan Hidup dan Kehutanan.

Prayogo H, Thohari AM, Solihin DD, Prasetyo LB, Jito S. 2016. Pemodelan kesesuaian habitat orangutan kalimantan (Pongo pygmaeus pygmaeus Linn, 1760) di koridor satwa Kapuas Hulu Kalimantan Barat. Jurnal Penelitian Hutan dan Konservasi Alam. 13(2): 137-150. doi: 10.20886/jphka.2016.13.2.

Purwadi. 2010. Karakteristik habitat preferensial orangutan Pongo pygmaeus wurmbii di Taman Nasional Sebangau [tesis]. Bogor (ID): Institut Pertanian Bogor.

Rijksen HD, Meijaard E. 1999. Our Vanishing Relative: The status of Wild Orang-utans at the close the Twentieth Century. Dordrecht (NL): Kluwer Academic Publisher.

Roberge JM, Angelstam P. 2004. Usefulness of the umbrella species concept as a conservation tool. Conservation Biology. 18(1): 76-85. doi: 10.1111/j.1523-1739.2004.00450.x.

Saura S, Pascual-Hortal L. 2007. A new habitat availability index to integrate connectivity in landscape conservation planning: Comparison with existing indices and application to acase study. Landscape and Urban Planning. 83: 91-103.

Siahaan L, Hilwan I, Setiawan Y. 2019. Spatial distribution of andaliman potential habitat (Zanthoxylum acanthopodium DC.) in Samosir Island, North Sumatera. JPSL. 9(4): 861-871. doi: http://dx.doi.org/10.29244/jps1.9.4.861-871.

Soehartono T, Susilo HD, Andayani N, Utami-Atmoko SS, Sihite J, Sales C, Sutrisno A. 2009. Strategi dan rencana aksi konservasi orang utan Indonesia 2007-2017. Jakarta (ID): Direktorat Jenderal Perlindungan Hutan dan Konservasi Alam, Departemen Kehutanan.

Soemarno K, Ramono WS, Tilson R. 1995. Introduction to the orangutan population and habitat viability analysis (PHVA) workshop. Di dalam: Nadler RD et al., editor. The Neglected Ape. New York (US): Plenum Press.

Stockwell DRB, Peterson AT. 2002. Effects of sample size on accuracy of species distribution models. Ecological Modelling. 148: 1-13.

Susilawati, Fauzi A, Kusmana C, Santoso N. 2020. Strategi dan kebijakan dalam pengelolaan wisata konservasi orangutan sumatera (Pongo abelii) di Bukit Lawang Kabupaten Langkat Sumatera Utara. JPSL. 10(1): 1-11. doi: http://dx.doi.org/10.29244/jpsl.10.1.1-11.

Syartinilia, Tsuyuki S. 2008. GIS-based modeling of Javan Hawk-Eagle distribution using logistic and autologistic regression models. Biological Conservation. 141(3): 756-769.

Uitgeverij W, van Hoeve BV. 2003. Ensiklopedi Indonesia Seri Fauna: Mamalia 1. Jakarta: PT. Ikrar Mandiriabadi.

Utami-Atmoko SS, Traylor-Hozler K, Rifqi MA, Siregar P, Achmad B, Priadjati A, Husson S, Wich SA, Hadisiswoyo P, Saputra F, et al., editors. 2017. The Orangutan Population And Habitat Viability Assessment 2017. Bogor (ID): The Directorate General of Natural Resources and Ecosystem Conservation, Ministry of Environment and Forestry of Indonesia.

van Schaik CP, Azwar, Priatna D. 1995. Population estimates and habitat preferences of orangutans based on line transects of nests. Di dalam: Nadler RD, Galdikas BMF, Sheeran LK, Rosen N, editor. The Neglected Ape. New York (US): Springer Science and Business Media.

Wich SA, Meijaard E, Marshall AJ, Husson S, Ancrenaz M, Lacy RC, van Schaik CP, Sugardjito J, Simorangkir T, Taylor-Holzer K, et al., 2008. Review: Distribution and conservation status of the orangutan (Pongo spp.) on Borneo and Sumatra: how many remain?. Fauna \& Flora International. 42(3): 329-339.

Xun B, Yu D, Liu Y. 2014. Habitat connectivity analysis for conservation implications in an urban area. Acta Ecologica Sinica. 34: 44-52. doi: 10.1016/j.chnaes.2013.11.006. 